\title{
Epigeal Fauna and Soil Chemical Attributes in Grazing and Regeneration Areas
}

\author{
Leandro Ribeiro Nogueira ${ }^{1}$, Marcos Gervasio Pereira ${ }^{2}$, Cristiane Figueira da Silva², \\ João Henrique Gaia-Gomes², Shirlei Almeida Assunção², \\ Eliane Maria Ribeiro da Silva ${ }^{3}$ \\ ${ }^{1}$ Departamento de Licenciatura em Geografia, Fundação Educacional Rosemar Pimentel, \\ Centro Universitário Geraldo Di Biase - UGB/FERP, Volta Redonda/RJ, Brazil \\ ${ }^{2}$ Departamento de Solos, Universidade Federal Rural do Rio de Janeiro - UFRRJ, Seropédica/RJ, Brazil \\ ${ }^{3}$ Laboratório de Micorrizas, Embrapa Agrobiologia - CNPAB, Seropédica/RJ, Brazil
}

\begin{abstract}
The objective of this study was to evaluate the influence of natural pasture and spontaneous regeneration on soil chemical properties and epigeal fauna community using a secondary Atlantic Forest as reference. The study areas were located in Passa Vinte, Minas Gerais, Brazil. In each study area, pitfall traps were used to sample epigeal fauna in the dry and rainy seasons. Earth samples were collected at a depth of $0-5 \mathrm{~cm}$ in the dry and rainy seasons for analysis of chemical attributes. The pasture and regeneration areas showed an overall activity of epigeal fauna and functional groups similar to the forest area. However, the diversity evaluated by the Shannon and Pielou evenness indices and the total richness were lower than the observed in the forest. The best fertility attributes were observed in the forest and pasture areas.
\end{abstract}

Keywords: land use, diversity, forest fragments.

\section{INTRODUCTION}

The Atlantic Forest is the most fragmented Brazilian biome and the second largest tropical rainforest in the Americas. It originally spread throughout an uninterrupted strip across the Brazilian coast (Fundação SOS Mata Atlântica, 2001). Although the Atlantic Forest is one of the hotspots on the planet in terms of biological diversity, it is also one of the most threatened biomes (Brasil, 2015). Because of anthropogenic interference (deforestation), most forest remnants in this biome are small, highly disturbed, isolated, little known, little protected (Menezes et al., 2009), and often surrounded by agricultural crops and pastures and regenerating forests.

Deforestation for agricultural purposes followed by pasture and/or spontaneous regeneration may generate a landscape with different levels of ecological degradation/restoration. The spontaneous regeneration is an essential process for restoration of degraded areas, since it promotes the addition of new individuals. The mechanisms involved in this process (seed falls, soil seed bank formation and seedling and young plant banks) increase the density and richness of species in the community and contribute to ecological succession and its biological diversity. Spontaneous regeneration can make ecological interrelations stronger and contribute to the restoration of the system, and also to its increase in complexity and consequent self-sustainability (Quintela, 2005), which is essential in the case of the Atlantic Forest.

Chemical, physical and biological soil attributes are among the main indicators for evaluating environmental restoration and degradation processes (Silva et al., 2012a; 
Guareschi et al., 2014). In particular, the epigeal fauna (a term used for invertebrates found in the leaf litter and in the soil) are considered key biological indicators (Menezes et al., 2009; Pereira et al., 2013; Silva et al., 2013). The epigeal fauna is sensitive to anthropogenic and natural interventions (Machado et al., 2015). They are involved in nutrient cycling, organic matter decomposition, and improvement of physical attributes (aggregation, porosity, and water infiltration) and participate in the soil biological functioning (Correia \& Oliveira, 2005; Batista et al., 2013). Monitoring the diversity of epigeal fauna groups helps understanding the function of these organisms and the ecological complexity of these communities (Moço et al., 2005).

Understanding fertility is also important for the assessment of the ecological environment. Different types of coverage and management systems can favorably or adversely affect soil chemical attributes (Guareschi et al., 2014; Moline \& Coutinho, 2015). Some studies (Melloni et al., 2008; Silva et al., 2012a) have found distinct patterns when comparing the soil fertility of pastures and secondary forests. Guareschi et al. (2014) found that secondary forest regeneration in the Atlantic Forest, regardless of the successional stage (advanced, medium or early), improved soil fertility (increased $\mathrm{Ca}, \mathrm{Mg}, \mathrm{K}$ and cation exchange capacity) in the topsoil layer compared to managed pasture. Conversely, Melloni et al. (2008) observed higher values for chemical attributes in pasture compared with native forest in this biome.

Monitoring changes that occur over time in farms and soil processes and, therefore, in environmental sustainability and quality in response to land use and agricultural management systems, is essential to assess the "health" of the ecosystem studied (Melloni et al., 2008).

The hypothesis of the present study is that natural pasture and spontaneous regeneration promote changes in the soil chemical and biological properties when compared to secondary Atlantic Forest. Thus, the aim of this study was to assess the effect of natural pasture and spontaneous regeneration on the soil chemical attributes and, specifically, on the epigeal fauna community in Atlantic Forest.

\section{MATERIAL AND METHODS}

The study was conducted at Palmital Farm in Passa Vinte, Minas Gerais (MG), Brazil (Figure 1), located at $22^{\circ} 12^{\prime}$ South latitude and $44^{\circ} 12^{\prime}$ West longitude,

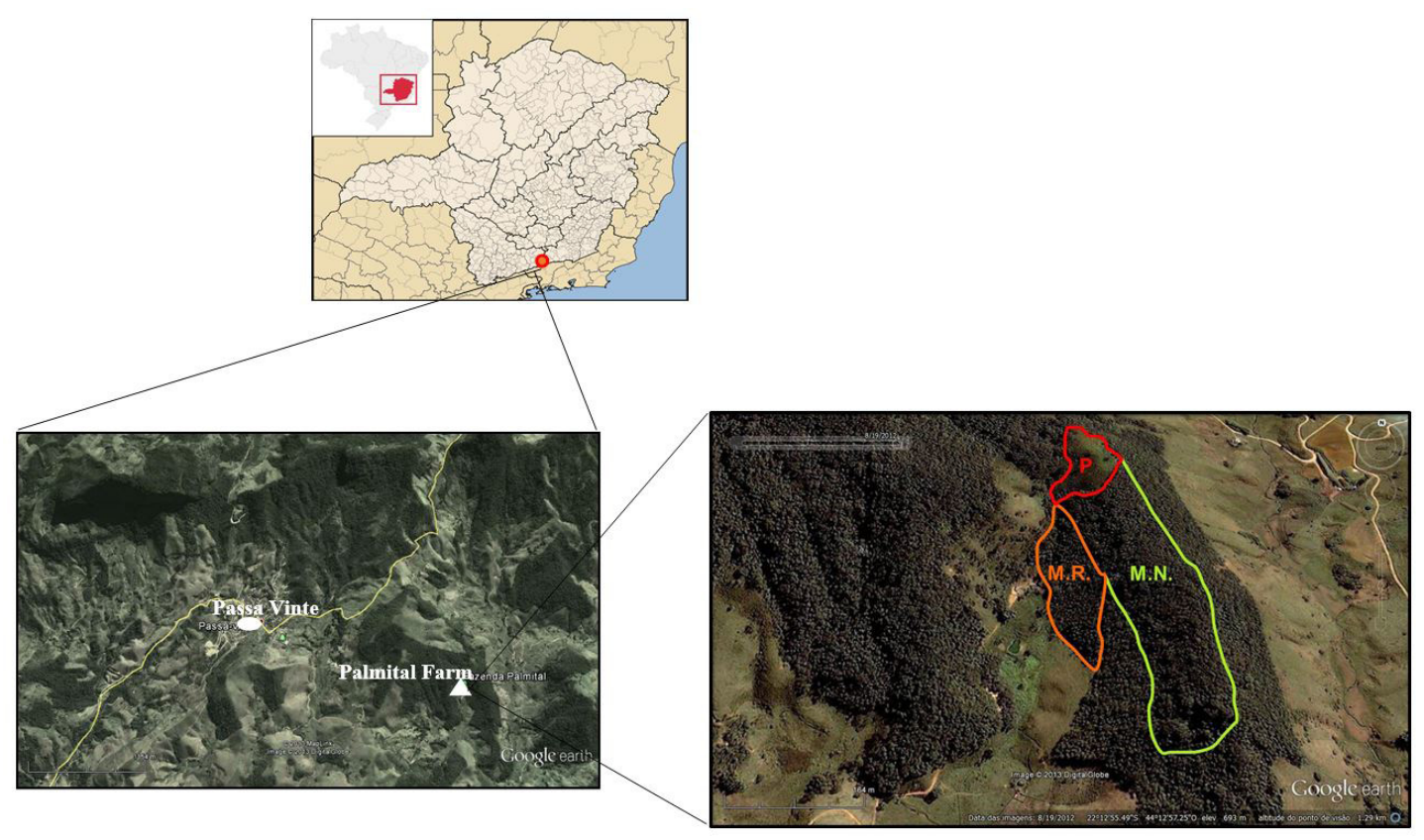

Figure 1. Map of the Palmital Farm, Passa Vinte MG, Brazil. Souce: IBGE (2015); Google Earth (2015). P = natural pasture; M.R. = spontaneous regeneration; M.N. = secondary forest. 
at 630 meters above sea level. The climate is tropical sub-humid (Aw), according to Köppen climate classification. The soil in the study area is classified as Argissolo Vermelho Amarelo (Ultisol) Ultisol (Santos et al., 2013), and the study area is located in a gently rolling to rolling terrain.

The study was carried out in the following areas: spontaneous regeneration, natural pasture and secondary forest (Figure 1). The regeneration area was located in the middle/lower third of a hill at the farm. This area was used as pasture until it was fenced to ensure that cattle would no longer have access to the area. The last mowing was done approximately 20 years ago. The natural pasture was located on a hilltop with a slope lower than $45^{\circ}$ facing west-southwest. Signal grass and low animal density and trampling predominated in the pasture, which had no fertilizing practices either. The forested area was located in the upper/middle region. This area consisted of Atlantic Forest with an ecosystem corresponding to submontane dense ombrophilous forest. There is no record of wood extraction in this area since the present owners purchased the farm, although historical characteristics, size and distribution of forest fragments in the region suggest that the area correspond to a secondary forest. Ecological characteristics indicate a long period of formation of this area, such as the presence of high biological diversity of large-sized animals, as reported by the farm owners.

A perimeter of $80 \times 25 \mathrm{~m}$ was defined in each study area for sample collection. Sampling was conducted in two different seasons (rainy and dry). Pitfall traps were used to sample the epigeal fauna community (Moldenke, 1994). The traps consisted of plastic bottles containing $4 \%$ formaldehyde to fix the organisms. A total of 20 traps were set in each area; ten in the dry season and ten in the rainy season. Each trap was buried in the ground until its opening was at the level of the leaf litter on the ground and was left open for seven days. Then, the samples were collected. The organisms were rinsed in water and stored in bottles with $70 \%$ ethanol for preservation.

Organisms were separated into taxonomic groups, mostly classified to the order level, using a stereoscopic binocular microscope. Furthermore, the orders were clustered into functional groups (Microphages - Entomobryomorpha and Poduromorpha;
Symphypleona; Saprophagous - Diplopoda, Isopoda, and Psocoptera; Predator - Araneae, Dermaptera, Hymenoptera, Opilionida, and Pseudoscorpionida; Saprophagous/Predator - Acari, Coleoptera, Formicidae, Isoptera, and Larvae; Herbivorous - Auchenorryncha, Heteroptera, Orthoptera, and Diptera) according to their main eating habits in the environment (Moço et al., 2005; Copatti \& Daudt, 2009; Menezes et al., 2009). The ecological attributes of the fauna were characterized based on their taxonomic composition (\%), density (number of individuals trap ${ }^{-1}$ day $^{-1}$ ), total richness (number of groups) and Shannon-Wiener diversity $\left(H^{\prime}\right)$ and Pielou evenness ( $\left.J^{\prime}\right)$ indices.

To evaluate the soil chemical attributes, five single soil samples were collected at a $0-5-\mathrm{cm}$ depth to form a composite sample, and a total of five composite samples were collected per area. The samples were air-dried, crushed and sieved through a 2-mm mesh to prepare air-dried fine soil (ADFS). The analysis of soil chemical attributes was performed according to EMBRAPA (1997). Soil attributed included organic carbon (OC), $\mathrm{pH}$ in water, aluminum (exchangeable $\mathrm{Al}), \mathrm{H}+\mathrm{Al}$ (exchangeable acidity), phosphorous (P), potassium (available $\mathrm{K}$ ), calcium $(\mathrm{Ca})$, and magnesium (exchangeable $\mathrm{Mg}$ ).

Normality of error distribution (Lilliefors test/SAEG 5.0) and homogeneity of variances (Cochran and Bartlett tests/SAEG 5.0) of collected data were checked. The mean values of the chemical attributes were compared using Bonferroni's t test at 5\% probability in Sisvar 4.6. Cluster analysis (simple connection; similarity measure: correlation) and principal components analysis were performed using PAST.

\section{RESULTS AND DISCUSSION}

\subsection{Epigeal fauna}

A total of 22 taxonomic groups were found in the regeneration, pasture and native forest areas. The relative distribution (RD\%) of half of these groups (Acari, Araneae, Coleoptera, Diptera, Entomobryomorpha, Formicidae, Hymenoptera, Coleoptera larvae, Orthoptera, Poduromorpha, and Symphypleona) was above $2 \%$ in at least one area (Figure 2). The other half (Auchenorrynca, Dermaptera, Heteroptera, Isoptera, Diptera larvae, Psocoptera, Isopoda, Diplopoda, Opilionida, Pseudoscorpionida, and Lepidoptera larvae) 
had an RD\% lower than $2 \%$ in one or more areas and was included in the category termed "Others".

The Acari, Araneae, Formicidae, Entomobryomorpha, Coleoptera, Coleoptera larvae and Orthoptera groups occurred in all areas and in both seasons evaluated. The Entomobryomorpha and Formicidae groups were the most frequent, corresponding to $46 \%$ (regeneration area) and $55 \%$ (pasture area) of the organisms in the rainy season, respectively (Figure 2). Organisms of the Collembola group (Entomobryomorpha) can be considered biological indicators of disturbance or soil quality (Baretta et al., 2008) because their family diversity and richness are sensitive to anthropogenic interactions and they become more abundant in increased soil organic matter levels (Fernandes et al., 2009).

Although the Formicidae group performs ecological functions such as seed dispersal, soil physical and chemical structuring, predation, and nutrient cycling (Doles et al., 2001), a high ratio of ants in an environment does not to necessarily indicate a more complex community structure (Silva et al., 2006a). These organisms adapt rapidly to local conditions. Thus, a predominance of

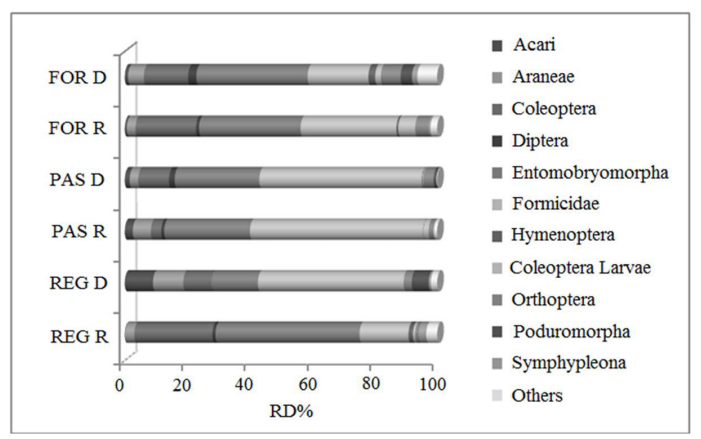

Figure 2. Relative distribution (RD\%) of epigeal fauna groups in the spontaneous regeneration (REG), pasture (PAS) and native forest (FOR) areas at Palmital Farm in Passa Vinte, Minas Gerais (MG), in the dry (D; 2013) and rainy $(\mathrm{R} ; 2014)$ seasons. one or more species may occur (Bruyn, 1999). However, different studies (Menezes et al., 2009; Silva et al., 2012b; Machado et al., 2015) have shown high ratios of Formicidae in areas of native forest whose systems have a better dynamic equilibrium with greater structural complexity, functional redundancy and increased control of ecological processes (Begon et al., 2005). Ants may occupy several positions in the food chain, and their effect on an ecosystem may vary considerably (Silva et al., 2012c). In the present study, ants accounted for more than $50 \%$ of the activity of epigeal organisms in the pasture, whereas the RD\% of the Formicidae group ranged from $16 \%$ to $45 \%$ in the regeneration area in the dry and rainy seasons, respectively (Figure 2).

The presence of one or more groups may be indicative of the quality of a specific environment even if the frequency of their occurrence is low (Cunha-Neto et al., 2012; Machado et al., 2015). The group classified as "Others" had low ratios in all areas evaluated, with percentages below 7\%, as observed in the forest area in the dry season (Figure 2). Among the 11 groups included in that category, Auchenorryncha, Dermaptera, Psocoptera and Diplopoda occurred exclusively in the forest area (Table 1), whereas the Isoptera group was found in all areas (Table 1). Conversely, the Pseudoscorpionida group, which is considered indicator of regeneration areas and has been found in areas with low levels of degradation (Pereira et al., 2013; Silva et al., 2009), was only observed in the forest and regeneration areas (Table 1 ).

Moço et al. (2005) reported the occurrence of Pseudoscorpionida in the soil community of preserved forest only; the group was absent in non-preserved forest. Cunha-Neto et al. (2012) and Moço et al. (2005) suggested that the occurrence of this group was related to a good environmental structure and was indicative of increased trophic structure control (Pereira et al., 2013). The Isopoda group was also exclusively observed in the

Table 1. Distribution of the group classified as "Others" in the spontaneous regeneration (REG), pasture (PAS) and native forest (FOR) areas at Palmital Farm in Passa Vinte, MG, in the dry (D) (2013) and rainy (R) seasons (2014).

\begin{tabular}{ccl} 
Areas & Seasons & \multicolumn{1}{c}{ Fauna group } \\
\multirow{2}{*}{ FOR } & $\mathrm{D}$ & Auchenorrynca, Dermaptera, Heteroptera, Isoptera, Diptera and Psocoptera larvae, Isopoda \\
& $\mathrm{R}$ & Diplopoda, Isopoda, Opilionida, Pseudoscorpionida \\
\multirow{2}{*}{ PAS } & $\mathrm{D}$ & Heteroptera \\
& $\mathrm{R}$ & Isoptera, Lepidoptera larvae, Opilionida \\
\multirow{2}{*}{ REG } & $\mathrm{D}$ & Isopoda, Diptera larvae, Pseudoscorpionida \\
& $\mathrm{R}$ & Isoptera, Lepidoptera larvae \\
\hline
\end{tabular}


forest and regeneration areas (Table 1). This group is essentially saprophagous and significantly contributes to leaf litter fragmentation and increased microbial colonization, thereby controlling a key stage of the decomposition process (Menezes et al., 2009).

The epigeal fauna community composition of the forest area had a similarity of approximately $60 \%$ with both the regeneration and the pasture areas in both seasons (Figure 3 ). This pattern most likely resulted from differences in the plant species composition and richness among the areas as well as differences in the vegetation structural complexity combined with habitat differences (i.e., light intensity, biomass and nutrient availability in the soil) (Guariguata \& Ostertag, 2001). These factors affect the composition and dynamics of the epigeal fauna (Machado et al., 2015).

In general, the systems did not differ in terms of functional groups. All systems contained microphages, herbivores, saprophages, predators, and simultaneous saprophages/predators. The microphage and saprophage/predator functional groups had higher activity than the other groups in all areas (Figure 4). The microphages (represented by the Collembola) are important organisms that are responsible for the predatory activity of microorganisms (Tordoff et al., 2008), an indirect contribution to soil fertility, enzyme production and organic matter fragmentation (Yang et al., 2012). The Collembola are widely distributed and abundant in the topsoil/leaf litter layer. Their abundance is affected by the presence of organic matter, and they are considered opportunistic because they grow rapidly under suitable conditions (Antoniolli et al., 2006). In turn, saprophages/predators are important for maintaining the ecological balance of the soil fauna and plant waste fragmentation. They contribute to leaf litter decomposition, organic waste redistribution and nutrient cycling in the environment (Correia \& Oliveira, 2000).

The total activity of the epigeal fauna was similar among the forest, regeneration and pasture areas in the dry season, whereas the pasture had the highest activity of these organisms in the rainy season (Table 2).

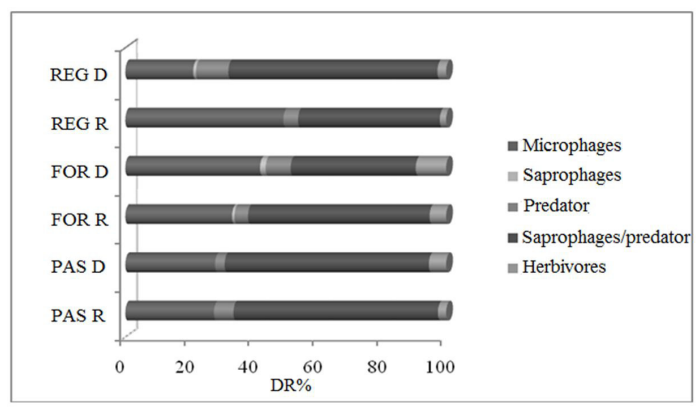

Figure 4. Relative distribution (RD\%) of epigeal functional groups in the spontaneous regeneration (REG), pasture (PAS) and native forest (FOR) areas at Palmital Farm in Passa Vinte, MG, in the dry (D; 2013) and rainy $(\mathrm{R} ; 2014)$ seasons.

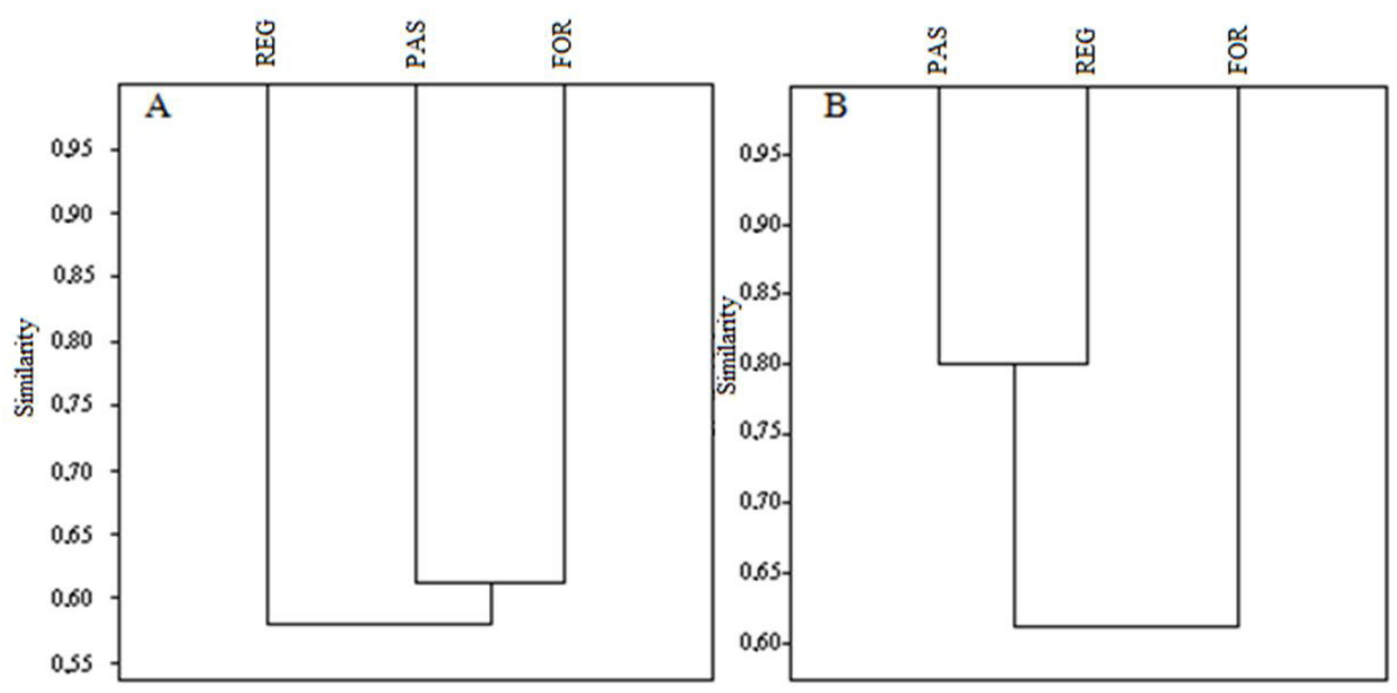

Figure 3. Similarity dendrogram (simple connection; similarity measure:correlation) of the occurrence of epigeal fauna taxonomic groups in spontaneous regeneration (REG), pasture (PAS) and native forest (FOR) areas at Palmital Farm in Passa Vinte, MG, in the dry and rainy seasons. (A) Dry season (2013); (B) Rainy season (2014). 
Furthermore, the pasture showed higher fauna activity in the rainy season than in the dry season (Table 2). This pattern resulted from the increased activity of the Formicidae group (approximately 130\%) in the rainy season.

The Shannon diversity index was highest (approximately $40 \%$ and $30 \%$ in the dry and rainy seasons, respectively) in the forested area, followed by the regeneration area; the index was lowest in the pasture in both seasons (Table 2). The Shannon diversity index considers both the richness of the groups and the distribution of the number of organisms within each group (i.e., the evenness). Greater total group richness and a higher Pielou evenness index were found in the forest area, especially in the dry season. Silva et al. (2012b) proposed that structurally more complex environments (i.e., with a higher structural diversity), such as forests, contribute to a greater diversity of soil fauna species (Copatti \& Daudt, 2009). This pattern most likely results from higher plant diversity and greater leaf litter heterogeneity (Correia \& Andrade, 2008), which provides an increased supply of ecological niches, refuges from predators, availability of nesting sites and food resources for these organisms (Copatti \& Daudt, 2009; Silva et al., 2012b). Some researchers (Menezes et al., 2009; Bartz et al., 2014) have suggested that native forests generally have higher soil fauna richness than pastures.

\subsection{Soil chemical attributes}

Soil $\mathrm{pH}$ variations were observed among the study areas in the dry season only. The $\mathrm{pH}$ values recorded in the native forest and spontaneous regeneration areas were lower than the values recorded in the pasture (Table 3). Silva et al. (2006b) proposed that the presence of a more acidic $\mathrm{pH}$ in forested areas might result from the continuous input of crude organic matter (OM) into the soil because the $\mathrm{OM}$ functional groups have the ability to release or accept $\mathrm{H}^{+}$ions (Meurer, 2000). Furthermore, decomposition and mineralization lead to the production of acidic organic substances that may reduce soil $\mathrm{pH}$, especially in the upper layers (Fialho et al., 1991). Notably, these areas had higher $\mathrm{Al}$ (forest and regeneration) and $\mathrm{H}+\mathrm{Al}$ (forest) levels

Table 2. Total activity (individual trap ${ }^{-1} \mathrm{day}^{-1}$ ) of the epigeal fauna, total richness (TR) and Shannon diversity and Pielou evenness indices in the spontaneous regeneration (REG), pasture (PAS) and native forest (FOR) areas at Palmital Farm in Passa Vinte, MG, in the dry and rainy seasons. D = dry season (2013); R = rainy season (2014).

\begin{tabular}{|c|c|c|c|c|c|c|c|c|}
\hline \multirow{2}{*}{ Areas } & \multicolumn{2}{|c|}{ Individual trap $^{-1}$ day $^{-1}$} & \multicolumn{2}{|c|}{ Shannon } & \multicolumn{2}{|c|}{ Pielou } & \multicolumn{2}{|c|}{ RT } \\
\hline & D & $\mathbf{R}$ & D & $\mathbf{R}$ & D & $\mathbf{R}$ & D & $\mathbf{R}$ \\
\hline FOR & $7.84 \pm 0.95^{\star} \mathrm{aA}$ & $7.47 \pm 1.30 \mathrm{bA}$ & 2.79 & 2.42 & 0.66 & 0.63 & 19 & 14 \\
\hline PAS & $7.98 \pm 1.60 \mathrm{aB}$ & $15.04 \pm 3.29 \mathrm{aA}$ & 2.03 & 1.88 & 0.59 & 0.51 & 11 & 13 \\
\hline REG & $6.81 \pm 1.28 \mathrm{aA}$ & $8.72 \pm 0.59 \mathrm{bA}$ & 2.48 & 2.11 & 0.69 & 0.57 & 12 & 13 \\
\hline
\end{tabular}

Means followed by the same uppercase letter in rows and lowercase letter in columns do not differ according to Bonferroni t tests at $5 \%$. ${ }^{*}$ Standard error.

Table 3. Chemical attributes of soil under the spontaneous regeneration (REG), pasture (PAS) and native forest (FOR) areas at Palmital Farm in Passa Vinte, MG, at 0-5-cm depths in the dry (D; 2013) and rainy (R; 2014) seasons.

\begin{tabular}{|c|c|c|c|c|c|c|c|c|}
\hline \multirow{3}{*}{ Areas } & \multirow{2}{*}{\multicolumn{2}{|c|}{$\mathbf{p H}$}} & \multicolumn{2}{|c|}{$\mathbf{C a}$} & \multicolumn{2}{|c|}{ Mg } & \multicolumn{2}{|c|}{$\mathbf{P}$} \\
\hline & & & \multicolumn{4}{|c|}{ 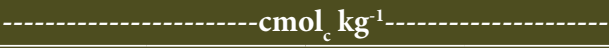 } & \multicolumn{2}{|c|}{$\mathrm{mg} \mathrm{kg}^{-1}$} \\
\hline & $\mathbf{D}$ & $\mathbf{R}$ & D & $\mathbf{R}$ & D & $\mathbf{R}$ & $\mathbf{D}$ & $\mathbf{R}$ \\
\hline FOR & $4.21 \mathrm{bA}$ & $4.35 \mathrm{aA}$ & $0.74 \mathrm{bA}$ & $0.91 \mathrm{aA}$ & $1.37 \mathrm{aA}$ & $1.10 \mathrm{aA}$ & $3.52 \mathrm{aA}$ & $3.19 \mathrm{aA}$ \\
\hline PAS & $5.07 \mathrm{aA}$ & $4.28 \mathrm{aB}$ & $1.84 \mathrm{aA}$ & $0.75 \mathrm{aB}$ & $2.12 \mathrm{aA}$ & $0.09 \mathrm{bB}$ & $2.53 \mathrm{bA}$ & $1.98 \mathrm{bA}$ \\
\hline REG & $4.41 \mathrm{bA}$ & $4.48 \mathrm{aA}$ & $0.33 \mathrm{bA}$ & $0.57 \mathrm{aA}$ & $0.37 \mathrm{bA}$ & $0.13 \mathrm{bA}$ & $1.74 \mathrm{cA}$ & $1.05 \mathrm{cB}$ \\
\hline \multirow{3}{*}{ Areas } & \multicolumn{2}{|c|}{$\mathbf{K}$} & \multicolumn{2}{|c|}{ Al } & \multicolumn{2}{|c|}{$\mathrm{H}+\mathrm{Al}$} & \multicolumn{2}{|c|}{$\mathrm{Na}$} \\
\hline & \multicolumn{8}{|c|}{ 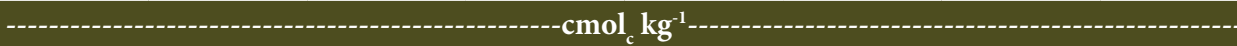 } \\
\hline & D & $\mathbf{R}$ & D & $\mathbf{R}$ & $\mathbf{D}$ & $\mathbf{R}$ & $\mathbf{D}$ & $\mathbf{R}$ \\
\hline FOR & $0.37 \mathrm{aA}$ & $0.08 \mathrm{aB}$ & $2.25 \mathrm{aA}$ & $2.28 \mathrm{aA}$ & $16.56 \mathrm{aB}$ & $24.97 \mathrm{aA}$ & $0.01 \mathrm{aA}$ & $0.03 \mathrm{aA}$ \\
\hline PAS & $0.36 \mathrm{aA}$ & $0.04 \mathrm{aB}$ & $0.34 \mathrm{bB}$ & $2.62 \mathrm{aA}$ & $7.85 \mathrm{bB}$ & $20.02 \mathrm{aA}$ & $0.02 \mathrm{aA}$ & $0.01 \mathrm{aA}$ \\
\hline REG & $0.16 \mathrm{bA}$ & $0.04 \mathrm{aB}$ & $1.93 \mathrm{aB}$ & $2.62 \mathrm{aA}$ & $9.21 \mathrm{bB}$ & $17.91 \mathrm{bA}$ & $0.01 \mathrm{aA}$ & $0.01 \mathrm{aA}$ \\
\hline
\end{tabular}

Means followed by the same uppercase letter in rows and lowercase letter in columns do not differ according to Bonferroni t tests at $5 \%$. 
than the pasture, which might have contributed to the lower $\mathrm{pH}$ values (Table 3). Similar patterns were observed by Guareschi et al. (2014) when studying the chemical attributes of pasture and forest fragment areas at different regeneration stages in Pinheiral, Rio de Janeiro. No significant differences were observed in the $\mathrm{pH}, \mathrm{Al}$ and $\mathrm{H}+\mathrm{Al}$ among the study areas during the rainy season.

$\mathrm{Ca}, \mathrm{Mg}, \mathrm{P}$ and $\mathrm{K}$ contents found in the regeneration area were mostly lower than those observed in the forest and pasture areas in the dry season (Table 3). In the rainy season, $\mathrm{Mg}$ and $\mathrm{P}$ exhibited a pattern that was similar to the dry season, with the lowest contents in the regeneration area, whereas $\mathrm{Ca}$ and $\mathrm{K}$ did not differ between areas (Table 3 ). The pasture had lower Mg (rainy season) and P (dry and rainy seasons) than the forest area, whereas the content of the other nutrients was higher than or similar to the forest (Table 3). Loss et al. (2014) observed higher K, $\mathrm{Ca}$ and $\mathrm{Mg}$ levels in pasture than in forested areas in an Argisol in the Brazilian state of Acre.

Low Na values were observed in all areas because the areas were located at high altitudes without marine influence that could increase the levels of this element.
The greatest variation in chemical attributes between the dry and rainy seasons was observed in the pasture, with $\mathrm{pH}$ values and $\mathrm{Ca}, \mathrm{Mg}$ and $\mathrm{K}$ levels decreasing and $\mathrm{Al}$ and $\mathrm{H}+\mathrm{Al}$ increasing from the dry to the rainy season (Table 3). Conversely, the native forest only exhibited variation in $\mathrm{K}$ and $\mathrm{H}+\mathrm{Al}$, with $\mathrm{K}$ decreasing and $\mathrm{H}+\mathrm{Al}$ increasing from the dry to the rainy season (Table 3). A decrease in $\mathrm{P}$ and $\mathrm{K}$ and an increase in $\mathrm{Al}$ and $\mathrm{H}+\mathrm{Al}$ were observed in the regeneration area from the dry to the rainy season (Table 3 ).

\subsection{Multivariate analysis}

The principal components analysis integrating the epigeal fauna community, chemical attributes (0-5-cm depth) and organic carbon (data not shown; 0-5-cm depth) indicated a separation among the three study areas through the relationship between principal component 1 (PC 1) and principal component 2 (PC 2) in the dry (Figure $4 \mathrm{~A}$ ) and rainy (Figure $5 \mathrm{~B}$ ) seasons. The Axis 1 (PC 1) explained $59.79 \%$ of the data variability and the $40.21 \%$ in the dry season (Figure $4 \mathrm{~A}$ ), whereas Axis 1 (PC 1) explained $64.34 \%$ and Axis 2 (PC 2) explained $35.66 \%$ in the rainy season (Figure $5 \mathrm{~B}$ ).

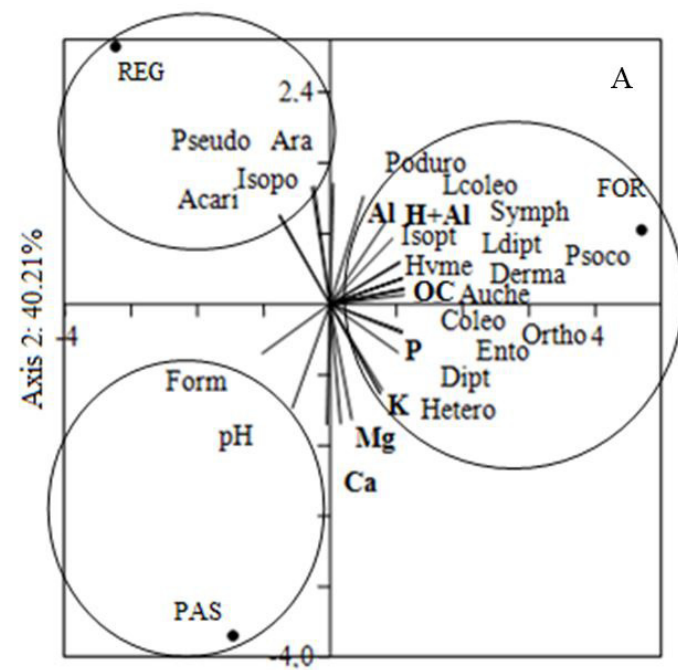

Axis $1: 59.79 \%$

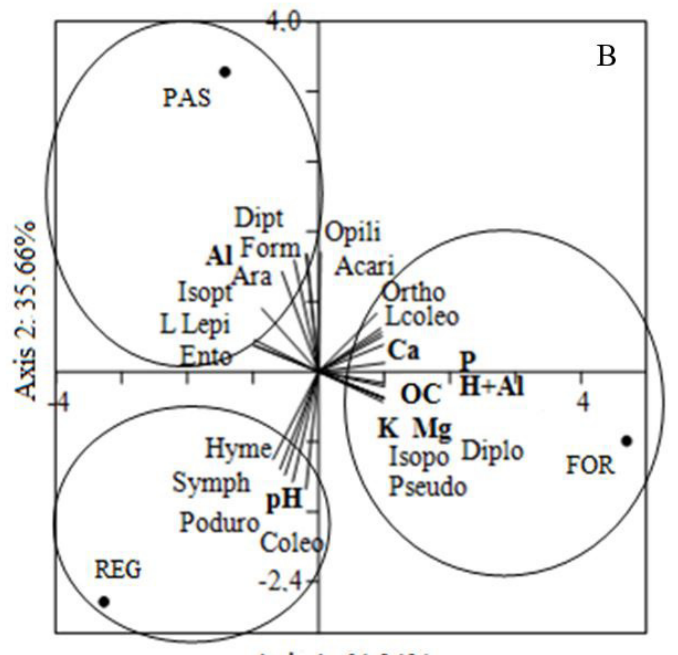

Axis $1: 64.34 \%$

Figure 5. Principal component analysis diagram integrating the epigeal fauna taxonomic groups, organic carbon (OC; $0-5-\mathrm{cm}$ depth) and soil chemical attributes (0-5-cm depth) in the spontaneous regeneration (REG), pasture (PAS) and native forest (FOR) areas at Palmital Farm in Passa Vinte, MG, in the dry (A) and rainy (B) seasons. Pseudo - Pseudoscorpionida; Ara - Aranae; Isopo - Isopoda; Poduro - Poduromorpha; Form - Formicidae; Lcoleo - Coleoptera Larvae; Shymph - Symphypleona; Isopt - Isoptera; Ldipt -Diptera Larvae; Psoco - Psocoptera; Derma - Dermaptera; Auche - Auchenorryncha; Coleo - Coleoptera; Ortho - Orthoptera; Hyme - Hymenoptera; Ento - Entomobryomorpha; Dipt - Diptera; Hetero - Heteroptera; Orthoptera; LLepi -Lepidoptera Larvae; Opili - Opilionida; Diplo - Diplopoda. 
The existence of three distinct clusters was observed along axis 1 (main axis) in both seasons (Figure $5 \mathrm{~A}$ and $5 \mathrm{~B}$ ): the forest area on the right, and the regeneration (upper quadrant in the dry season and lower quadrant in the rainy season) and pasture (lower quadrant in the dry season and upper quadrant in the rainy season) areas on the left. In the dry season, most groups were associated with the forested area, which was more strongly correlated with $\mathrm{OC}$ and most of the soil chemical attributes (P, K, Al and $\mathrm{H}+\mathrm{Al}$; Figure $4 \mathrm{~A})$. In this season, only Isopoda, Pseudoscorpionida, Acari and Araneae out of the 20 taxonomic groups recorded were more closely associated with the regeneration area, whereas only Formicidae was more closely associated with the pasture (Figure 5A).

These results indicate that a greater balance and diversity of factors (habitat, chemical elements and food availability) in natural ecosystems can favor the maintenance of invertebrate soil fauna (Portilho et al., 2011). According to some authors (Portilho et al., 2011; Vendrame et al., 2009), soil chemical attributes affect organisms of the soil fauna. Vendrame et al. (2009) evaluated a Latosol in the Cerrado biome under a pasture area, and found greater density of Isoptera in soils with low exchangeable $\mathrm{Ca}+\mathrm{Mg}$ and greater diversity of Hemiptera and larvae of Coleoptera in soils with high total organic carbon contents. In the present study, the same pattern was found for Coleoptera larvae, while the Isoptera order tended to be associated with areas with low $\mathrm{Ca}$ and $\mathrm{Mg}$ contents (Figure 5A and 5B).

Conversely, a more even distribution of the groups among the areas was seen in the rainy season (Figure 5B), although the forest area remained more closely correlated with most of the soil chemical attributes $(\mathrm{Ca}, \mathrm{Mg}, \mathrm{P}, \mathrm{K}$, and $\mathrm{H}+\mathrm{Al})$ and the $\mathrm{OC}$. The Formicidae group remained more closely associated with the pasture; however, in the rainy season, Diptera, Araneae, Isoptera, Lepidoptera larvae and Entomobryomorpha were also present. The Diplopoda, Isopoda, Pseudoscorpionida, Orthoptera and Coleoptera larvae groups were more closely associated with the forest, whereas the Hymenoptera, Symphypleona, Poduromorpha and Coleoptera groups were correlated with the regeneration area.

Thus, effects of both soil management system and season (dry and rainy) were observed on the epigeal fauna dynamics, which most likely resulted from not only the possible effect of soil chemical attributes but also the plant community structure and composition and climate conditions, including the presence of rainfall, which modifies the moisture content in microenvironments (Silva et al., 2012b; Abreu et al., 2014).

\section{CONCLUSIONS}

The spontaneous regeneration and pasture areas shows total activity of epigeal fauna and their functional groups were similar to the forest area.

The diversity, as evaluated through the Shannon diversity and Pielou evenness indices (dry and rainy seasons), and the total richness (dry season) of the spontaneous regeneration and pasture areas were lower than the observed in the forest.

The best soil fertility attributes are found in the native forest and natural pasture areas.

The fallow time in the regeneration area has not been enough for the chemical attributes to reach the values observed in the forested area in the dry season.

\section{SUBMISSION STATUS}

Received: 2 aug., 2016

Accepted: 28 aug., 2016

\section{CORRESPONDENCE TO}

\section{Marcos Gervasio Pereira}

Departamento de Solos, Universidade Federal Rural do Rio de Janeiro - UFRRJ, BR 465, Km 7 , CEP 23890-000, Seropédica, RJ, Brazil e-mail: mgervasiopereira01@gmail.com

\section{REFERENCES}

Abreu RRL, Lima SS, Oliveira NCR, Leite LFC. Fauna edáfica sob diferentes níveis de palhada em cultivo de cana-de-açúcar. Pesquisa Agropecuária Tropical 2014; 44(4): 409-416. http://dx.doi.org/10.1590/S198340632014000400002 .

Antoniolli ZI, Conceição PC, Böck V, Port O, Silva DM, Silva RF. Método alternativo para estudar a fauna do solo. Ciência Florestal 2006; 16(4): 407-417. http://dx.doi. org/10.5902/198050981922.

Baretta D, Ferreira CS, Sousa JP, Cardoso EJBN. Colêmbolos (Hexapoda: collembola) como bioindicadores de qualidade do solo em áreas com Araucaria angustifolia. Revista 
Brasileira de Ciência do Solo 2008; 32(spe): 2693-2699. http://dx.doi.org/10.1590/S0100-06832008000700012.

Bartz MLC, Brown GG, Orso R, Mafra AL, Baretta D. The influence of land use systems on soil and surface litter fauna in the western region of Santa Catarina. Revista Ciência Agronômica 2014; 45(5): 880-887. http://dx.doi. org/10.1590/S1806-66902014000500003.

Batista I, Fernandes ME, Pereira MG, Bieluczyk W, Schiavo JA, Mello NA. Caracterização dos agregados em solos sob cultivo no Cerrado, MS. Semina: Ciências Agrárias 2013; 34(4): 1535-1548.

Begon M, Townsend CR, Harper JL. Ecology from individuals to ecosystems. Malden: Blackwell Publishing; 2005.

Brasil. Ministério do Meio Ambiente - MMA. Mata Atlântica online]. Brasília; 2015. [cited 2015 May 15]. Available from: http://www.mma.gov.br/biomas/mata-atlantica

Bruyn LAL. Ants as bioindicators of soil function in rural environments. Agriculture, Ecosystems \& Environment 1999; 74(1-3): 425-441. http://dx.doi.org/10.1016/S01678809(99)00047-X.

Copatti CE, Daudt CR. Diversidade de artrópodes na serapilheira em fragmentos de mata nativa e Pinus elliottii (Engelm. Var elliottii). Ciência e Natura 2009; 31(1): 95-113.

Correia MEF, Andrade AG. Formação de serapilheira e ciclagem de nutrientes. In: Santos GA, Silva LS, Canellas LP Camargo FAO, editores. Fundamentos da matéria orgânica do solo: ecossistemas tropicais e subtropicais. Porto Alegre: Metrópole; 2008.

Correia MEF, Oliveira LCM. Fauna do solo: aspectos gerais e metodológicos. Seropédica: Embrapa Agrobiologia; 2000.

Correia MEF, Oliveira LCM. Importância da fauna de solo para a ciclagem de nutrientes. In: Aquino AM, Assis RL, editores. Processos biológicos no sistema solo-planta: ferramentas para uma agricultura sustentável. Brasília: Embrapa Informação Tecnológica; 2005.

Cunha-Neto FV, Correia MEF, Pereira GHA, Pereira MG, Leles PSSV. Soil fauna as an indicator of soil quality in forest stands, pasture and secondary forest. Revista Brasileira de Ciência do Solo 2012; 36(5): 1407-1417. http://dx.doi. org/10.1590/S0100-06832012000500004.

Doles JL, Zimmerman RJ, Moore JC. Soil microarthorod community structure and dynamics in organic and conventionally managed apple orchads in western colorad, USA. Applied Soil Ecology 2001; 18(1): 83-96. http://dx.doi. org/10.1016/S0929-1393(01)00143-3.

Empresa Brasileira de Pesquisa Agropecuária - EMBRAPA. Manual de métodos de análises de solo. 1. ed. Rio de Janeiro: Embrapa; 1997.

Fernandes LH, Nessimian JL, Mendonça MC. Structure of Poduromorpha (Collembola) communities in "restinga" environments in Brazil. Pesquisa Agropecuária Brasileira 2009; 44(8): 1033-1039. http://dx.doi.org/10.1590/S0100204X2009000800036.
Fialho JF, Borges AC, Barros NF. Cobertura vegetal e as caracteristicas quimicas fisicas e atividades e atividades da microbiota de urn Latossolo Vermelho-Amarelo distrofico. Revista Brasileira de Ciência do Solo 1991; 15: 21-28.

Fundação SOS Mata Atlântica. A Mata Atlântica [online]. São Paulo: Fundação SOS Mata Atlântica; 2001. [cited 2015 May 15]. Available from: http://www.aliancamataatlantica. org.br $/$ ? $\mathrm{p}=2$

Google Earth [online]. 2015. [cited 2015 May 15]. Available from: https://www.google.com/earth

Guareschi RF, Pereira MG, Menezes CEG, Anjos LHC, Correia MEF. Atributos químicos e físicos do solo sob pastagem e estádios sucessionais de floresta estacional. Revista de la Facultad de Agronomía 2014; 113(1): 47-56.

Guariguata MR, Ostertag R. Neotropical secondary forest succession: changes in structural and functional characteristics. Forest Ecology and Management 2001; 148(1-3): 185-206. http://dx.doi.org/10.1016/S03781127(00)00535-1.

Instituto Brasileiro de Geografia e Estatística - IBGE [online]. 2015. [cited 2015 May 15]. Available from: http://www.ibge.gov.br

Loss A, Pereira MG, Bernini TA, Zatorre NP, Wadt PGS. Fertilidade do solo e matéria orgânica em Vertissolo e Argissolo sob cobertura florestal e pastagem. Comunicata Scientiae 2014; 5(1): 1-10.

Machado DL, Pereira MG, Correia MEF, Diniz AR, Menezes CEG. Fauna edáfica na dinâmica sucessional da mata atlântica em floresta estacional semidecidual na bacia do rio Paraíba do Sul - RJ. Ciência Florestal 2015; 25(1): 91-106. http://dx.doi.org/10.5902/1980509817466.

Melloni R, Melloni EGP, Alvarenga MIN. Indicadores da qualidade do solo. Informe Agropecuário 2008; 29: 17-29.

Menezes CEG, Correia MEF, Pereira MG, Batista I, Rodrigues KM, Couto WH et al. Macrofauna edáfica em estádios sucessionais de floresta estacional semidecidual e pastagem mista em Pinheiral (RJ). Revista Brasileira de Ciência do Solo 2009; 33(6): 1647-1656. http://dx.doi. org/10.1590/S0100-06832009000600013.

Meurer EJ. Fundamentos de química do solo. Porto Alegre: Genesis; 2000.

Moço MKS, Gama-Rodrigues EF, Gama-Rodrigues AC, Correia MEF. Caracterização da fauna edáfica em diferentes coberturas vegetais na região norte fluminense. Revista Brasileira de Ciência do Solo 2005; 29(4): 565-571. http:// dx.doi.org/10.1590/S0100-06832005000400008.

Moldenke AR. Arthropods. In: Weaver RW, Angle S, Bottomley P, Bezdicek D, Smith S, Tabatabai A et al., editors. Methods of soil analysis. Part 2: microbial and biochemical properties. Madison: SSSA; 1994.

Moline EFV, Coutinho ELM. Atributos químicos de solos da Amazônia Ocidental após sucessão da mata nativa em áreas de cultivo. Revista de Ciências Agrárias 2015; 58(1): 14-20. http://dx.doi.org/10.4322/rca.1683.

Pereira GHA, Pereira MG, Anjos LHC, Amorim TA, Menezes CEG. Decomposição da serrapilheira, diversidade e funcionalidade de invertebrados do solo em um 
fragmento de floresta atlântica. Bioscience Journal 2013; 29(1): 1317-1327.

Portilho IIR, Crepaldi RA, Borges CD, Silva RF, Salton JC, Mercante FM. Fauna invertebrada e atributos físicos e químicos do solo em sistemas de integração lavoura-pecuária. Pesquisa Agropecuária Brasileira 2011; 46(10): 1310-1320. http://dx.doi.org/10.1590/S0100-204X2011001000027.

Quintela MF. O papel da regeneração natural na recuperação de áreas degradadas. In: Garay I, Becker BK, editores. Dimensões humanas da biodiversidade. Petrópolis: Vozes; 2005.

Santos HG, Jacomine PKT, Anjos LHC, Oliveira VA, Lumbreras JF, Coelho MR et al. Sistema brasileiro de classificação de solos. Brasília: Embrapa; 2013.

Silva RF, Aquino AM, Mercante MF, Guimarães MF. Macrofauna invertebrada do solo sob diferentes sistemas de produção em Latossolo da Região do Cerrado. Pesquisa Agropecuaria Brasileira 2006a; 41(4): 697-704. http:// dx.doi.org/10.1590/S0100-204X2006000400022.

Silva CF, Pereira MG, Loss A, Silva EMR, Correia MEF. Alterações químicas e físicas do solo em áreas de agricultura no entorno do Parque Estadual da Serra do Mar, Ubatuba (SP). Revista de Ciências Agrárias 2006b; 46: 9-28.

Silva CF, Pereira MG, Correia MEF, Silva EMR. Fauna edáfica em áreas de agricultura tradicional no entorno do Parque Estadual da Serra do Mar em Ubatuba (SP). Revista de Ciências Agrárias 2009; 52: 107-115.

Silva CF, Pereira MG, Miguel DL, Feitora JCF, Loss A, Menezes CEG et al. Carbono orgânico total, biomassa microbiana e atividade enzimática do solo de áreas agrícolas, florestais e pastagem no médio Vale do Paraíba do Sul (RJ). Revista Brasileira de Ciência do Solo 2012a; 36(6): 1680-1689. http://dx.doi.org/10.1590/S010006832012000600002 .

Silva J, Jucksch I, Tavares RC. Invertebrados edáficos em diferentes sistemas de manejo do cafeeiro na Zona da Mata de Minas Gerais. Revista Brasileira de Agroecologia 2012b; 7(2): 112-125.

Silva J, Jucksch I, Maia CI, Feres A, Tavares RC. Fauna do solo em sistemas de manejo com café. Journal of Biotechnology and Biodiversity 2012c; 3(2): 59-71.

Silva CF, Martins MA, Silva EMR, Pereira MG, Correia MEF. Influência do sistema de plantio sobre atributos dendrométricos e fauna edáfica, em área degradada pela extração de argila. Revista Brasileira de Ciencia do Solo 2013; 37(6): 1742-1751. http://dx.doi.org/10.1590/ S0100-06832013000600030.

Tordoff GM, Boddy L, Jones TH. Species-specific impacts of Collembola grazing on fungal foraging ecology. Soil Biology \& Biochemistry 2008; 40(2): 434-442. http://dx.doi. org/10.1016/j.soilbio.2007.09.006.

Vendrame PRS, Marchão RL, Brito OR, Guimarães MF, Becquer T. Relationship between macrofauna, mineralogy and exchangeable calcium and magnesium in Cerrado Oxisols under pasture. Pesquisa Agropecuaria Brasileira 2009; 44(8): 996-1001. http://dx.doi.org/10.1590/S0100204X2009000800031.

Yang X, Yang Z, Warren MW, Chen J. Mechanical fragmentation enhances the contribution of Collembola to leaf litter decomposition. European Journal of Soil Biology 2012; 53: 23-31. http://dx.doi.org/10.1016/j. ejsobi.2012.07.006. 